\title{
The Role of the Tripartite Glutamatergic Synapse in the Pathophysiology of Alzheimer's Disease
}

\author{
Carolyn C. Rudy ${ }^{1}$, Holly C. Hunsberger ${ }^{1}$, Daniel S. Weitzner ${ }^{1}$, Miranda N. Reed ${ }^{1.2 .3 *}$ \\ ${ }^{1}$ Behavioral Neuroscience, Department of Psychology, ${ }^{2}$ Center for Neuroscience, ${ }^{3}$ Center for Basic and \\ Translational Stroke Research, West Virginia University, Morgantown, WV, 26506, USA
}

[Received March 14, 2014; Revised April 22, 2014; Accepted April 23, 2014]

\begin{abstract}
Alzheimer's disease (AD) is the most common form of dementia in individuals over 65 years

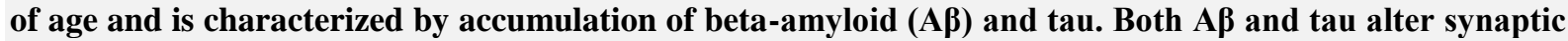
plasticity, leading to synapse loss, neural network dysfunction, and eventually neuron loss. However, the exact mechanism by which these proteins cause neurodegeneration is still not clear. A growing body of evidence suggests perturbations in the glutamatergic tripartite synapse, comprised of a presynaptic terminal, a postsynaptic spine, and an astrocytic process, may underlie the pathogenic mechanisms of AD. Glutamate is the primary excitatory neurotransmitter in the brain and plays an important role in learning and memory, but alterations in glutamatergic signaling can lead to excitotoxicity. This review discusses the ways in which both beta-amyloid (Aß) and tau act alone and in concert to perturb synaptic functioning of the tripartite synapse, including alterations in glutamate release, astrocytic uptake, and receptor signaling. Particular emphasis is given to the role of $\mathrm{N}$-methyl-D-aspartate (NMDA) as a possible convergence point for $A \beta$ and tau toxicity.
\end{abstract}

Key words: Beta-amyloid, tau, Alzheimer's disease, excitotoxicity, glutamate, NMDA, astrocytes, tripartite synapse

Alzheimer's disease (AD) affects one in every nine adults age 65 and older and is the sixth leading cause of death in the United States [1]. By 2025, the number of individuals 65 years of age and older with $\mathrm{AD}$ is expected to reach 7.1 million, and this number is projected to reach 13.8 million people by 2050 [1]. AD is characterized by progressive memory loss, decline in cognitive skills, and adverse behavioral changes [2]. Biologically, $\mathrm{AD}$ is characterized by an abundance of extracellular amyloid plaques comprised of insoluble beta-amyloid $(\mathrm{A} \beta)$, and intracellular neurofibrillary tangles containing hyperphosphorylated tau protein [3]. The third major feature of $\mathrm{AD}$ is an alteration of neuronal connections, eventually leading to massive neuron loss throughout the brain.
The best correlate of memory deficits in $\mathrm{AD}$ patients, however, is not $\mathrm{A} \beta$ plaque burden or neurofibrillary tangles, but synapse loss [4]. Similarly, synaptic dysfunction is observed prior to neuron loss in mouse models of $\mathrm{AD}$ and coincides with the onset of memory deficits $[5,6]$. Emerging evidence suggests early cognitive decline in AD may result from a dysregulation of excitatory glutamatergic neurotransmission by soluble $A \beta$, leading to synaptic alterations and tau phosphorylation [e.g., 7].

Glutamate, the major excitatory neurotransmitter, is responsible for many of the brain's functions including cognition and memory $[8,9]$. Glutamate is believed to contribute to hippocampal-dependent learning and memory through long-term potentiation (LTP) [10], a

*Correspondence should be addressed to: Miranda Reed, Ph.D. Behavioral Neuroscience, Department of Psychology,

West Virginia University, 53 Campus Drive, Morgantown, WV 26506-6040, USA. Email: Miranda.Reed@mail.wvu.edu 
long-lasting strengthening in signal transmission between two neurons that results from their synchronous stimulation $[11,12]$. Although beneficial at low levels, high concentrations of extracellular glutamate can lead to cell death through excessive activation of glutamate receptors, a process referred to as excitotoxicity [13]. Even at normal concentrations of glutamate, excitotoxicity can ensue if abnormalities in the glutamate receptors occur, such as tau-induced alterations in the phosphorylation of N-methyl-D-aspartate receptors (NMDARs) [14].

Excitotoxicity is linked to several neurodegenerative disorders, including $\mathrm{AD}$ [15], and occurs when uncontrolled glutamate release surpasses the capacity of astrocytic clearance mechanisms, leading to an overabundance of extracellular glutamate and excessive activation of extrasynaptic N-methyl-Daspartate receptors (E-NMDARs) [16]. Because glutamatergic neurotransmission occurs mainly within the confines of the tripartite synapse, focus will be given to the ways in which these components of the synapse become deregulated during $\mathrm{AD}$, with particular emphasis on consequences for E-NMDAR activation.

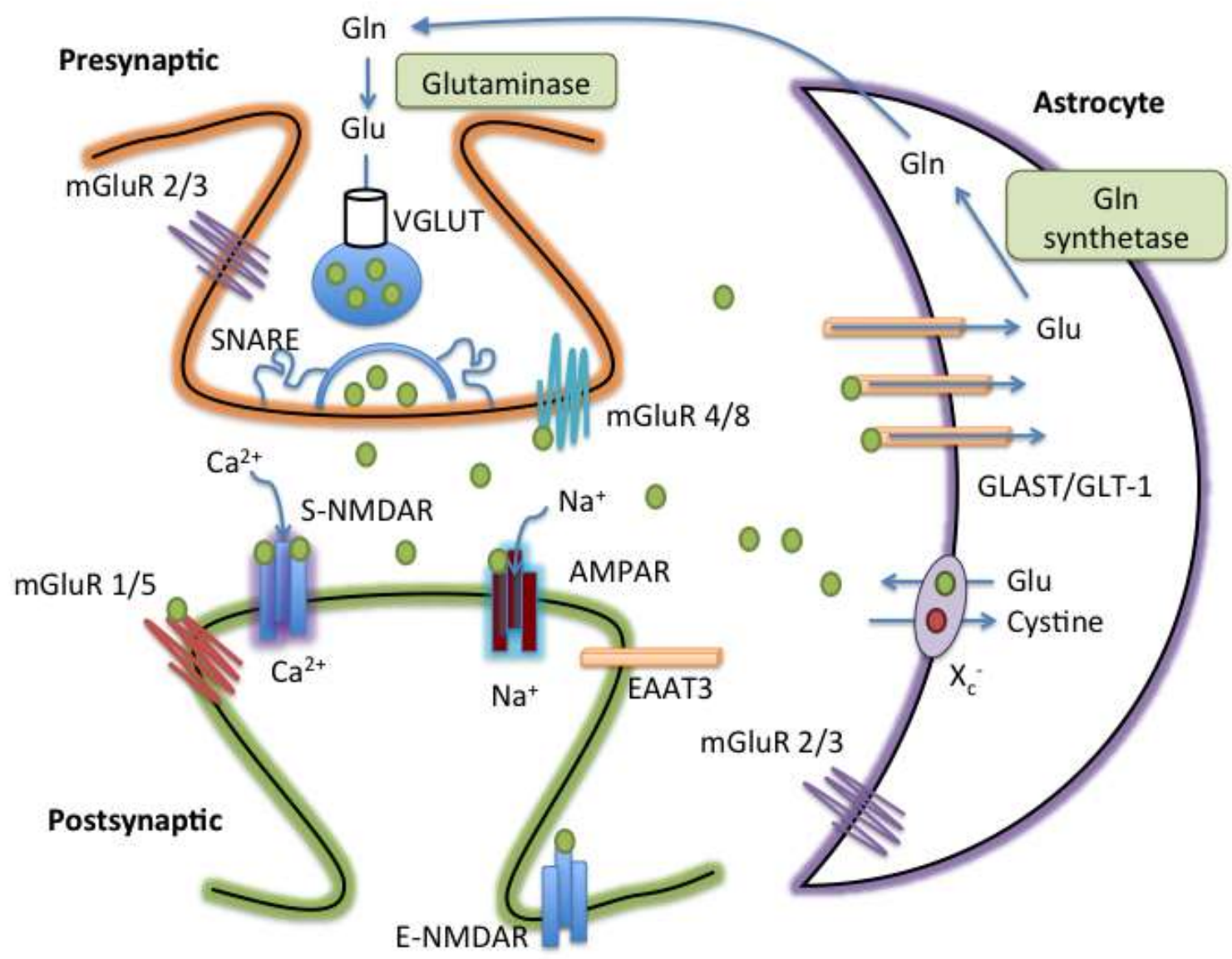

Figure 1. The tripartite glutamate synapse. In the presynaptic neuron, glutamine (Gln) is converted to glutamate (Glu) by glutaminase and packaged into synaptic vesicles by the vesicular glutamate transporter (VGLUT). SNARE complex proteins mediate the fusion of vesicles with the presynaptic membrane. Astrocytes also release glutamate via the cystine-glutamate antiporter $\left(\mathrm{X}_{\mathrm{c}}{ }^{-}\right)$. Following release into the extracellular space, glutamate binds to presynaptic (mGluR2/3 and mGluR4/8), synaptic (S-NMDAR and AMPAR) and peri-/extra- synaptic (mGluR1/5 and E-NMDAR) glutamate receptors. Glutamate is cleared from the synaptic space through excitatory amino acid transporters (EAATs) on neighboring astrocytes (GLAST and GLT-1) and, to a lesser extent, on neurons (EAAT3). Glutamate is converted to glutamine by glutamine synthetase within the astrocyte before being transported to presynaptic neurons, thereby completing the glutamate-glutamine cycle. 
Table 1. Primary locations and functions of metabotropic glutamate receptors in the tripartite synapse.

\begin{tabular}{|c|c|c|c|c|}
\hline $\begin{array}{l}\text { mGluR } \\
\text { Group }\end{array}$ & Subtype & $\begin{array}{c}\text { Glutamate } \\
\text { Receptor Affinity } \\
\left(\text { EC }_{50}\right)[178]\end{array}$ & Location* & Function* \\
\hline \multirow{2}{*}{ Group I } & mGluR1 & 9 & \multirow[t]{2}{*}{ Postsynaptic [179] } & $\begin{array}{l}\text { Enhances excitability, synaptic plasticity, } \\
\text { LTP/LTD }[180,181]\end{array}$ \\
\hline & mGluR5 & 10 & & Elevates intracellular calcium $[183,184]$ \\
\hline \multirow{2}{*}{ Group II } & mGluR2 & 4 & Presynaptic & $\begin{array}{l}\text { Inhibition of presynaptic glutamate [185]; } \\
\text { LTD [186] }\end{array}$ \\
\hline & mGluR3 & 3 & Astrocytes [187] & Inhibition of cystine/glutamate antiporter [26] \\
\hline \multirow{3}{*}{ Group III } & mGluR4 & 5 & Presynaptic [188] & Inhibition of presynaptic glutamate [189] \\
\hline & mGluR7 & 1000 & \multirow{2}{*}{ Astrocytes [190] } & \multirow{2}{*}{ Increases glutamate uptake [187] } \\
\hline & mGluR8 & $2.5[191]$ & & \\
\hline
\end{tabular}

* Though these receptors are located elsewhere and have additional functions, this table describes the most described, and believed to be primary, locations and functions of these receptors as they relate to the tripartite synapse.

\section{The Tripartite Glutamate Synapse}

The term "tripartite synapse," proposed twenty years ago to describe communication between neurons and astrocytes [17], encompasses a presynaptic terminal, a postsynaptic spine, and an astrocytic process (Figure 1). Within the tripartite synapse are multiple sites that regulate extracellular glutamate levels and are sensitive to AD-related pathology. Below, the normal physiological processes regulating extracellular glutamate are briefly described, followed by descriptions of how these targets are deregulated in AD.

Glutamate can be synthesized de novo from glucose through the Krebs/tricarboxylic acid cycle [18] or through recycling of glutamate by the astrocyteneuronal, glutamate-glutamine cycle. In the glutamateglutamine cycle, glutamate is synaptically released and taken up by surrounding astrocytes, where it is converted to glutamine, a non-neuroexcitatory amino acid, and transferred back to neurons for conversion to glutamate [19]. Glutamate is then packaged presynaptically into synaptic vesicles by vesicular glutamate transporters (VGLUTs). Though VGLUTs were once thought to be found in astrocytes, more recent evidence suggests that VGLUTs are not expressed in astrocytes, at least in the mouse brain [20]. Following presynaptic neuronal depolarization, calcium channels open, permitting the influx of calcium and triggering the fusion of vesicles with the membrane, resulting in the exocytosis of glutamate into the synapse [21, 22]. However, glutamate release is not limited to presynaptic neurons. Astrocytes also exhibit calcium-dependent glutamate release [23, 24] and release glutamate via the cystine-glutamate antiporter (Xc-) [25], a sodium-independent anionic amino acid transporter that exchanges a molecule of glutamate into the extrasynaptic space in exchange for a molecule of cystine transported into astrocytes $[25,26]$.

Once in the extracellular space, glutamate can bind to ionotropic (iGluR) or metabotropic (mGluR1-8) receptors $[27,28]$. The iGLuRs include N-methyl-Daspartate (NMDA), $\quad \alpha$-amino-3-hydroxy-5methylisoxazole-4-propionic acid (AMPA), and 2carboxy-3-carboxymethyl-4-isopropenylpyrrolidine

(KA) [29]. iGLuRs are ligand-gated ion channels that mediate the majority of excitatory neurotransmission and synaptic plasticity [27, 30, 31]. Within each class, receptors have distinct functional properties that arise from the homo-oligomeric, or hetero-oligomeric, assembly of distinct subunits into cation-selective tetramers [32-36]. 
Both AMPA and KA receptors are involved in fast synaptic transmission; glutamate binding to these receptors results in a conformational change and sodium influx $[37,38]$. In contrast, NMDA receptors do not participate in fast synaptic transmission. At resting potential, the NMDA receptor channel is blocked, in a voltage-dependent manner, by magnesium. Removal of magnesium requires depolarization of the postsynaptic neuron, which typically occurs after glutamate binds AMPA or KA receptors, leading to an influx of sodium [39-41]. In addition, NMDA receptors require the binding of glutamate, as well as a co-agonist, glycine or D-serine, to open the ion channel [42-44]. If both ligands (glutamate and a co-agonist) bind while the postsynaptic neuron is in a depolarized state, NMDA channels will open, permitting calcium to enter the cell [45]. Because NMDA receptors require concomitant presynaptic (release of glutamate) and postsynaptic (depolarization) activities, NMDA receptors detect the coincidence of two events and are sometimes referred to as coincidence detectors. In addition, NMDA receptors have a higher permeability to calcium than AMPA or KA receptors $[46,47]$. The increased influx of calcium triggers secondary messenger systems leading to the establishment of LTP, a process believed to underlie learning and memory [10]. Overactivation of NMDA receptors, however, leads to an excess of intracellular calcium, which initiates a series of events leading to cell death [48-50], a process described in detail in the next section.

The mGLuRs are G-protein coupled receptors with a seven putative trans-membrane spanning domain [51]. This large domain selectively binds glutamate and activates second messenger systems [52-55], resulting in a modulatory role in the central nervous system (CNS) function of neuronal excitability and neurotransmitter release. Unlike fast synaptic transmission of ionotropic receptors, mGLuRs are involved in slow synaptic transmission and are subdivided into 3 groups, Groups I, II, and III, on the basis of signal transduction pathways and pharmacological profiles [53] (see Table 1). Group I mGluRs are positively coupled to phospholipase C [56], whereas Groups II and III mGluRs are negatively coupled to adenylyl cyclase [57-60]. All three groups of mGLuRs, with the exception of mGluR 6, play a role in regulating hippocampal function.

Regulation of extracellular concentrations of glutamate is essential. Over-stimulation can erode synaptic regulation, leading to alterations in learning and memory, and more concerning, neurodegeneration throughout vulnerable networks [61]. Because there are no extracellular enzymes to degrade glutamate, the only way to terminate glutamate signaling, and to keep extracellular glutamate levels low, is through uptake of glutamate by one of five sodium-dependent excitatory amino acid transporters (EAATs) [62]. Only EAAT1 and EAAT2, also referred to as GLAST and GLT-1, respectively, are expressed in rodent brains [62]. GLAST and GLT-1 are primarily responsible for glutamate uptake and are located on astrocytes [63, 64]. EAAT3 is present on postsynaptic neurons in the in the CA1 region of the hippocampus and the granular layer of the dentate gyrus, and its uptake of glutamate is sodium dependent [65]. Whereas GLAST and GLT-1 are found only in the brain, EAAT3 can also be found in the intestines, kidney, liver, and heart [66]. CNS expression of EAAT3 is relatively low compared to that of GLT and GLAST [67]. EAAT4 is expressed primarily in the cerebellar Purkinje cells, while EAAT5 is found in retinal neurons and is involved in visual processing [68].

When uncontrolled glutamate release surpasses the capacity of astrocyte clearance mechanisms, or when the function or expression of EAATs is decreased, excessive activation of glutamate receptors can occur, a process referred to as excitotoxicity. Of particular relevance to the process of excitotoxicity are NMDA receptors.

\section{Synaptic vs. Extrasynaptic NMDARs}

NMDARs are essential mediators of synaptic plasticity and transmission [10]. There are seven NMDA receptor subunits (NR1, NR2A-D, and NR3A-B) forming heteromeric complexes containing NR1 subunits and a combination of NR2 and/or NR3 subunits. NR1 and NR3 bind to glycine [69], whereas NR2 binds to glutamate [70]. Because NR3A is restricted to expression during development [71] and NR3B is restricted to brain regions not involved in early stages of $\mathrm{AD}$ (i.e., the somatic motor neurons of the brainstem and spinal cord [72]), focus will be given to NR1/NR2 complexes. Likewise, NR1/NR2 complexes play an important role in learning and memory [73], as well as in excitotoxicity [74], and are abundantly located in the hippocampus, one of the first regions affected in $\mathrm{AD}$ [75-77].

NMDA receptors can be found synaptically, perisynaptically, or extrasynaptically [78]. Synaptic NMDA receptors (S-NMDARs) are activated by presynaptic glutamate release [79], whereas perisynaptic NMDA receptors are located $200-300 \mathrm{~nm}$ from the postsynaptic density [80] and are activated only by high glutamate concentrations [78]. Extrasynaptic NMDA receptors (E-NMDARs) are located on the spine neck, dendritic shaft, or soma [81] and also require high glutamate concentrations [78]. In addition, many ENMDARs are adjacent to glia [82] Thus, it is possible 
that astrocytic release of glutamate may result in activation of E-NMDARs.

Activation of S-NMDARs, which predominantly contain the NR2A subunit, mediates neuronal survival and resistance to trauma via their anti-apoptotic and antioxidant effects $[16,83]$. In contrast, activation of ENMDARs (predominately containing the NR2B subunit) is associated with neurotoxicity by stimulating cell death pathways $[16,83]$. S-NMDAR receptors primarily use D-serine, released by neighboring astrocytes, as their coagonist [84], whereas E-NMDARs are believed to use glycine as their co-agonist [85]. The relative difference in co-agonist use by S-NMDARs and E-NMDARs might be explained by the differential localization of NR2A and NR2B subunits, respectively, as NR2B-containing receptors have a tenfold higher affinity for glycine than NR2A-containing receptors $[70,86]$. Similarly, the localized release and astrocytic uptake of these coagonists has also been hypothesized to explain the differences in co-agonist use by S-NMDARs vs. ENMDARs (see [87, 88] for review). Further work is needed in this area, as a better understanding of the role of NMDAR co-agonists may have therapeutic implications.

The pathways triggered by E-NMDARs are not directly related to calcium overload; even after triggering equivalent calcium concentrations, the downstream events for synaptic and extrasynaptic receptors differ ([16] and see [15] for review) and are often in direct opposition to one another. One particularly relevant example for $\mathrm{AD}$ includes the differential effects on CREB (cyclic cAMP response element binding protein), a transcription factor essential for the conversion of short to long-term memory [89-91]. S-NMDARs activate CREB [16], whereas E-NMDARs inactivate CREB, and this inactivation dominates over the effects of $\mathrm{S}$ NMDAR activation [16, 92].

Alterations in CREB activity are not only important for learning and memory but also for neuroprotection. Increases in CREB signaling following activation of SNMDARs result in increased expression of brain-derived neurotrophic factor (BDNF) [16], essential for neuronal survival [93]. S-NMDAR activation also suppresses apoptotic signaling and increases antioxidant defenses. For example, activation of S-NMDARs suppresses forkhead box O (FOXO), a transcription factor involved in the regulation of oxidative stress and the modulation of genes involved in apoptosis [94].

Many of the signaling pathways activated by ENMDARs are in direct antagonism to those activated by S-NMDARs. As with CREB activity [16], the extracellular signal-regulated kinase (ERK1/2) pathway is bidirectionally modulated by S-NMDARs and E-
NMDARs, with E-NMDARs exerting a dominant ERK shutoff pathway [95]. Because ERK is crucial in memory consolidation and synaptic plasticity [96], shutoff of this pathway represents another way in which E-NMDAR activation is detrimental to learning and memory. Similarly, the suppression of FOXO activity by SNMDAR signaling is opposite to that observed following E-NMDAR activation; E-NMDAR activation increases FOXO activation, leading to excitotoxic cell death [97].

In addition to the direct antagonism of S-NMDAR pathways, activation of E-NMDARs also affects pathways not involved in S-NMDAR signaling. For example, S-NMDAR activation does not affect calpain activity, whereas E-NMDAR stimulation invokes calpain-mediated cleavage of striatal enriched tyrosine phosphatase (STEP) into an inactive form [98]. This inactive form of STEP is unable to dephosphorylate its substrates, including the stress-activated protein kinase, p38, and the Src kinase family member, Fyn, leading to an overactivation of these substrates following STEP cleavage. Activation of p38 is closely linked with cell death [99]; however, the consequences of increased Fyn activity are less clear and only recently recognized. One consequence of increased Fyn activity is an increase in the surface expression of NR2B [98]. Fyn phosphorylates the Tyr1472 residue of the NR2B subunit, leading to exocytosis of NMDAR complexes to neuronal surfaces [100]. When E-NMDAR stimulation inactivates STEP, STEP can no longer deactivate Fyn, leading to increased Fyn activity and exocytosis of NR2B receptors [101]. In addition, STEP dephosphorylates the Tyr1472 residue, promoting internationalization [102]. Thus, inactivating STEP leads to decreased endocytosis and increased exocytosis of NR2B receptors [101]. This increase in NR2Bcontaining receptors may then lead to an increase in ENMDAR signaling, thereby creating a self-perpetuating, feed-forward loop of excitotoxicity.

Increased activation of E-NMDARs may also mediate tau pathology in AD. Increased activation of NR2B-containing receptors induces tau phosphorylation, while blockade of NR2B receptors prevents this phosphorylation [103]. Likewise, blockade of extrasynaptic NR2B receptors abolishes tau-mediated cytotoxicity in a cell culture system [104]. Memantine, used to treat $\mathrm{AD}$, preferentially blocks E-NMDARs at low doses, while sparing normal synaptic activity [105]. Memantine treatment reduces tau phosphorylation [106] and excitotoxicity [107] while increasing memory functioning [108]. The following sections will provide evidence that glutamate can accumulate extracellularly to reach pathological levels as the tripartite synapse becomes deregulated in $\mathrm{AD}$. 


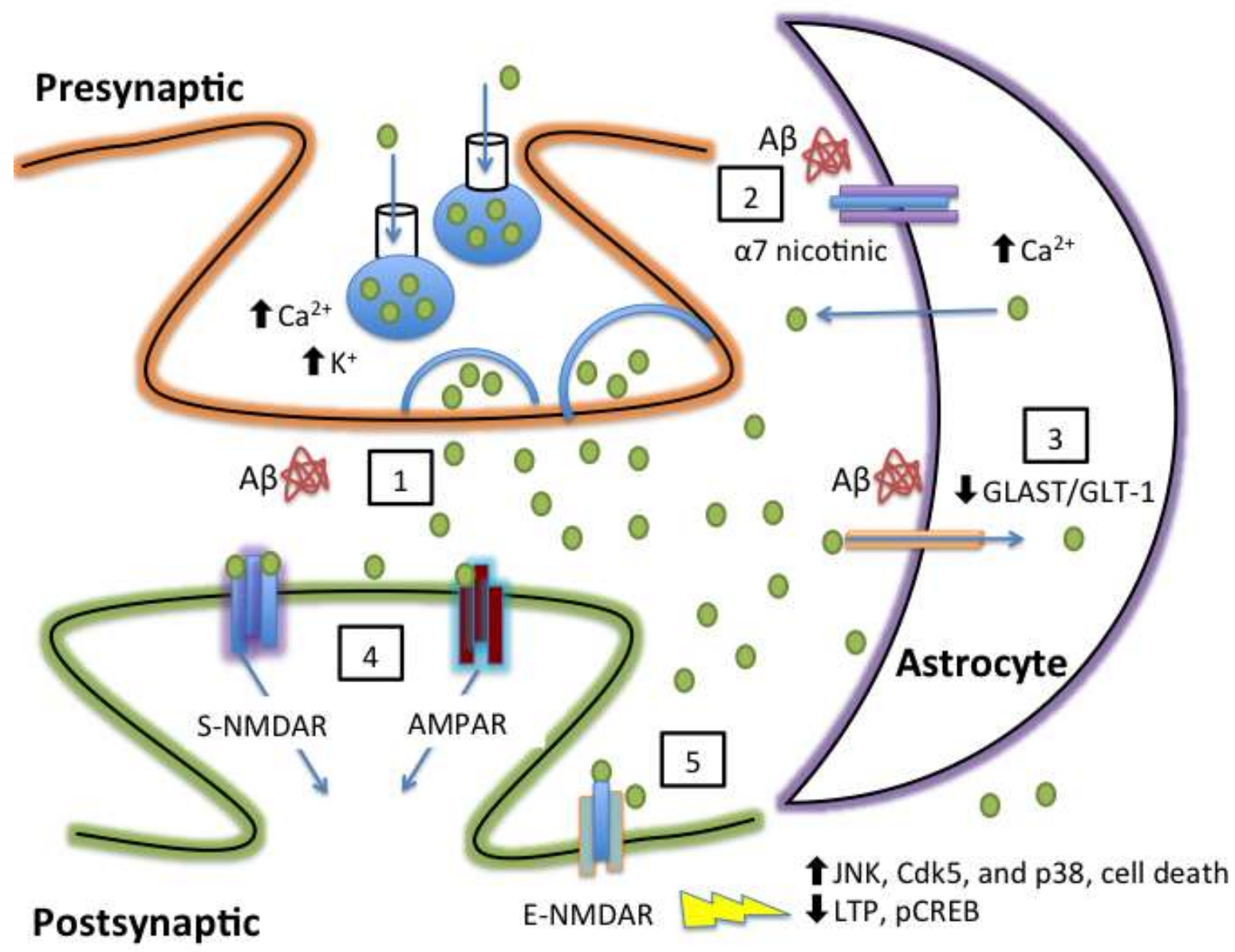

Figure 2. A $\beta$-mediated increases in extracellular glutamate and the resulting excitotoxicity. (1) A $\beta$ increases presynaptic release of glutamate. (2) A $\beta$ elevates astrocytic calcium via stimulation of astrocytic $\alpha 7$ nicotinic receptors, resulting in astrocytic glutamate release via an unknown mechanism. (3) A $\beta$ decreases glutamate clearance from the synapse, thereby prolonging the duration of glutamate in the synapse and potentially resulting in the spread of glutamate to neighboring synapses. (4) Prolonged activation of S-NMDARs and AMPARs resulting from increased extracellular glutamate is predicted to cause desensitization and internalization of NMDA/AMPA, resulting in synaptic depression. (5) Glutamate spillover activates E-NMDARs, resulting in multiple deleterious downstream events, including an increase in tau kinase activity, cell death, and blockade of long-term potentiation (LTP) and CREB phosphorylation (pCREB).

\section{A $\beta$ and Excitotoxicity}

Beta-amyloid $(A \beta)$ has long been implicated in the pathogenesis of $A D$ [109-113]. According to the original amyloid cascade hypothesis [114], the mismetabolism of the amyloid precursor protein (APP) results in increased amyloid plaque deposition (the insoluble deposits of extracellular $A \beta$ ) and a pathological cascade leading to neurofibrillary tangle formation and neuronal death. However, more recent studies have resulted in a reformulation of the amyloid cascade hypothesis with a shifted focus from amyloid plaques to increases in soluble oligomeric $A \beta$ as the more likely initiating event in $\mathrm{AD}$ [115-120]. $\mathrm{A} \beta$ plaques and, in particular, soluble oligomers, have been tied to disruptions in glutamate synaptic transmission [5, 6, 121-124] and can result in excitotoxicity through several different routes, including stimulation of glutamate release, inhibition of glutamate uptake, and alteration of signaling pathways related to activation of glutamatergic receptors (Figure 2). 
$\mathrm{A} \beta$ can increase glutamate release from neurons $[125,126]$ and astrocytes [127-129], resulting in abnormally high extracellular levels capable of activating the pathological E-NMDARs. A $325-35$ (1 $100 \mathrm{uM}$ ), a particularly toxic $A \beta$ fragment, increases potassium-induced release of both aspartate and glutamate in cultured hippocampal neurons, an effect dependent on calcium; interestingly, basal release of glutamate and potassium-induced glutamate release is exacerbated in slices from aged rats exposed to A $\beta 25-35$ compared to slices from young rats, suggesting one way in which aging might increase the risk for AD [125]. Soluble A $\beta$ oligomers also promote extracellular accumulation of glutamate by increasing the release of presynaptic vesicles, resulting in increased postsynaptic activity [126]. This $A \beta$ oligomer-induced release of glutamate is blocked by a sodium channel blocker (tetrodotoxin), an NMDAR antagonist (MK-801), or the removal of calcium from the extracellular medium, suggesting a dependence on excitatory neuronal activity [126].

$\mathrm{A} \beta$ has primarily been shown to stimulate glutamate release through its action on glia [127-129]. Picomolar concentrations of $A \beta 1-42$ elevate astrocytic calcium via stimulation of astrocytic $\alpha 7$ nicotinic receptors, resulting in astrocytic glutamate release in rat hippocampal slices $[127,128]$. As with the neuronal release of glutamate [130], the activation of E-NMDARs is a primary route by which downstream toxicity occurs; $A \beta$-induced astrocytic glutamate release increases E-NMDAR currents and decreases S-NMDAR currents, leading to synapse loss [128].

Another way in which $A \beta$ can increase extracellular concentrations of glutamate is by inhibition of astrocytic uptake, resulting in an increased duration of glutamate in the synaptic cleft [131-135]. In cultured astrocytes, surface expression of GLT-1, but not GLAST, is reduced following incubation with $A \beta 1-42(500 \mathrm{nM})$ [133]. In the hippocampus of mice, however, the expression of both GLT-1 and GLAST is reduced following injection of A $\beta 1-40$ (400 pmol/site) [135]. Similarly, GLT-1 and GLAST uptake activity is inhibited following the administration of either $\mathrm{A} \beta 1-40(5 \mu \mathrm{M})$ or $\mathrm{A} \beta 1-42(5$ $\mu \mathrm{M})$ to cultured astrocytes [132]; this decrease in transporter activity is due to a decrease in transporter expression resulting from $A \beta$-mediated phosphorylation/activation of astrocytic mitogenactivated protein (MAP) kinases, including ERK and JNK [132]. Altered activity of MAP kinase cascades results from the oxidative stress conditions induced by $A \beta$ [132], and anti-oxidant pretreatment can prevent the $A \beta$-mediated decrease in astrocytic uptake of glutamate [133]. The ability of $A \beta$ to almost double the amount of time required to clear synaptically released glutamate suggests $A \beta$ may promote the spread of glutamate from one synaptic domain to the next [133]. Such a spread could potentially alter the activity of entire neuronal networks.

Inhibition of glutamate reuptake is not limited to astrocytes; in cultured microglia, $\mathrm{A} \beta 25-35$ (5 uM) treatment also increases extracellular glutamate concentration via the reverse glutamate transporter [129]. Recent work suggests the $A \beta$-mediated changes in glutamate uptake may further increase $A \beta$ levels and cognitive impairment; mice lacking one allele for GLT-1 crossed with transgenic mice expressing mutations of APP and presenilin-1 (AßPPswe/PS1 $\triangle \mathrm{E} 9)$ exhibited earlier memory deficits and an increase in $A \beta 42 / A \beta 40$ compared to A $\beta P P s w e / P S 1 \Delta E 9$ mice [136]. Alterations in GLT-1 have also been observed in mild cognitive impairment (MCI) and AD patients, with the severity of detergent-insoluble GLT-1 associated with disease progression [137].

Astrocytes not only maintain healthy glutamate levels, but also have the capacity to clear and degrade $A \beta$ $[138,139]$. Astrocytes express $A \beta$-degrading proteases, including neprilysin and insulin-degrading enzyme [140]. There is an age-related downregulation of these $A \beta$-degrading proteases [141], suggesting one way in which $A \beta$ levels may increase with age. Of particular interest to the current review is recent work showing that MK-801 and ketamine, both non-competitive NMDAR antagonists, decrease the expression of neprilysin, but not insulin-degrading enzyme, resulting in decreased $A \beta$ degradation [140]. Though the decreased neprilysin expression is associated with a reduction in p38 MAPK phosphorylation [140], the exact mechanism by which NMDAR antagonism decreases $A \beta$ degradation is not known and warrants further investigation.

One consequence of increased $A \beta$ release is an increase in glutamate spillover and activation of ENMDARs [128, 130]. Accumulating evidence for the link among $\mathrm{A} \beta$, glutamate excitotoxicity, and $\mathrm{E}-$ NMDARs has stemmed in part from the ability of various NMDAR antagonists to prevent or reverse $A \beta$ related damage to neuronal and glial cultures. Although many early studies investigating the role of $A \beta$ in excitotoxicity used high concentrations of synthetic $A \beta$ (upwards of $20 \mu \mathrm{M}$ and higher than that found in healthy brains), recent work suggests the application of much lower $\mathrm{A} \beta$ concentrations also results in dramatic synapse loss, reactive oxygen species production, and cell death (e.g., $[123,142])$. Even picomolar concentrations of A $\beta$ incubated with organotypic hippocampal cultures results in perturbed NMDAR-dependent signaling and progressive loss of synapses and spines, whereas 
blockade of NMDARs prevents the loss of hippocampal synapses [123]. A slightly higher concentration of oligomeric $A \beta 1-42(1 \mu \mathrm{M})$ in cultured cortical neurons leads to activation of NADPH oxidase and a subsequent increase in reactive oxygen species production [142]. The reactive oxygen species trigger ERK1/2 activation and arachidonic acid release, effects reversed by a selective NMDAR antagonist, D-APV $(10 \mu \mathrm{M})$, as well as memantine $(5 \mu 1)$ [142]. A $\beta$-induced activation of $E$ NMDARs also results in toxic levels of nitrous oxide and abnormally high levels of caspase-3 activity that contribute to synaptic spine loss as a result of excessive calcium influx [128].

\section{(A) Healthy Control}

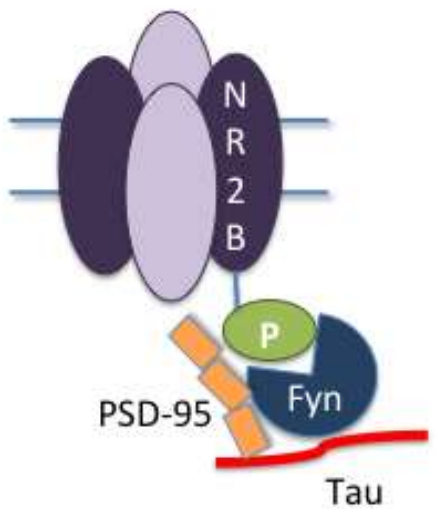

(B) Presence of $A \beta \&$ Tau Pathology
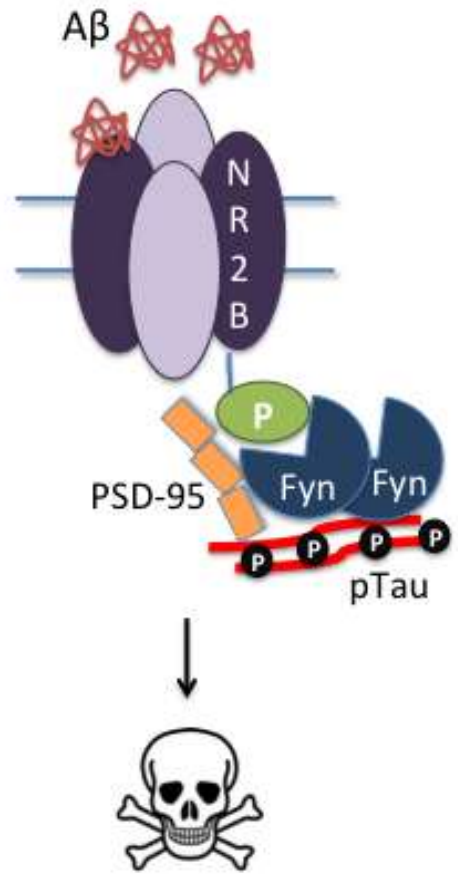

(C) Absence of Fyn or Tau

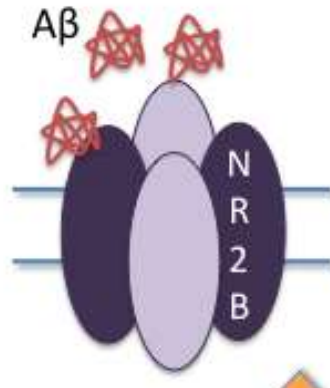

PSD-95

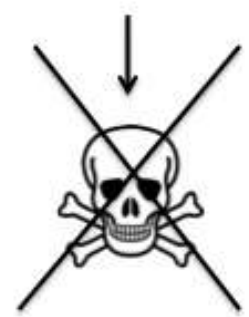

Figure 3. Tau-mediated excitotoxicity. (A) In healthy neurons, tau transports Fyn to the dendritic spine where Fyn, a tyrosine kinase that phosphorylates the NR2B receptor subunit Tyr ${ }^{1472}$, stabilizes the NR2B:PSD95 complex. (B) In the presence of A $\beta$ and/or hyperphosphorylated tau (ptau), stabilization of the NR2B:PSD95 complex enhances glutamatergic excitotoxicity. (C) Removal of tau or Fyn prevents glutamatergic excitotoxicity mediated by $\mathrm{A} \beta$.

A $\beta$ oligomers can shift the activation of NMDARdependent signaling pathways toward those involved in the impairment of LTP and the induction of long-term depression (LTD), effects observed in both neuronal cultures and in vivo [121-124, 143-147]. The mechanism by which A $\beta$ impairs LTP has yet to be completely elucidated, but it may involve the extreme permeability of the membrane to calcium and subsequent reactive oxygen species production [144], effects potentially mediated by E-NMDARs and mGluR5 activation. Application of A $\beta 1-42(1-100 \mathrm{nM})$ to cultured hippocampal slices results in blockade of LTP, an effect prevented by inhibition of E-NMDARs with memantine [143] or inhibitors of pathways downstream of ENMDAR activation, including JNK, Cdk5, and p38 inhibitors [146]. Because mGluR5 receptors are 
mechanistically coupled to NMDARs, NMDA excitotoxicity can be mediated by mGluR 5 activity, creating a positive feedback loop whereby activation of one potentiates the activity of the other [148, 149]. Inhibition of mGluR5 activity prevents the block of LTP induced by $A \beta[143,146]$ and is neuroprotective against $\mathrm{A} \beta[150-153]$.

In addition to decreasing LTP, A $\beta$ can also induce LTD [124, 147, 154]. For example, the addition of soluble $\mathrm{A} \beta 1-42(500 \mathrm{nM}-2 \mu \mathrm{M})$ to hippocampal slices results in enhanced LTD that is induced by lowfrequency stimulation [154]. The exact mechanism by which A $\beta$ induces LTD has not yet been elucidated, though the necessity of the mitogen-activated protein kinase, p38, has been suggested by some [154], but not all, studies [124]. Similarly, there is not a consensus as to whether $A \beta$-mediated LTD is NMDAR-dependent. Some studies contend that A $\beta$-mediated LTD is mGluR-, but not NMDAR-, dependent [154]; addition of a nonselective Group I/II mGluR antagonist, LY341495 $(10 \mu \mathrm{M})$, enhances A $\mathrm{A}$-mediated LTD, whereas application of an NMDAR antagonist, D-AP5 $(50 \mu \mathrm{M})$, has no effect [154]. However, it has been noted that whether A $\beta$-enhanced LTD is mediated by mGluR or NMDAR activity depends not only on the induction protocol used, but also on the dose of AP5 (50 vs 100 uM) [124].

Thus, the $A \beta$-mediated increase in glutamate resulting from increased glutamate release, either from presynaptic neurons or astrocytes, is predicted to initially activate S-NMDARs. However, prolonged activation may result in desensitization and ultimately synaptic depression, possibly via internalization of NMDA/AMPA receptors. The increased levels would also spillover to activate E-NMDARs, resulting in LTD and blockade of LTP. Finally, the A $\beta$-mediated decreases in glutamate clearance may result in the spread of glutamate to neighboring synapses, thereby altering neuronal network activity.

The link between $A \beta$ and glutamate excitotoxicity has been firmly established in the literature. However, only in the last decade has the role of tau in glutamate excitotoxicity been examined. The essential role of tau in mediating $\mathrm{A} \beta$ toxicity, as well as tau's direct effects on glutamate dysregulation, will be explored below.

\section{Tau and Excitotoxicity}

Although historically studied less than $\mathrm{A} \beta$, tau has also been implicated in glutamate excitotoxicity and synaptic dysfunction (Figure 3). The role of tau in glutamate excitotoxicity is established in part by findings that NMDAR antagonists prevent tau-mediated cell death [e.g., 104]. Much like with A $\beta$, soluble tau, as opposed to tangles, is the more toxic species $[155,156]$ and can cause synaptic dysfunction independently of $A \beta$ (see [157] for review). For example, we have shown that tau phosphorylation results in mislocalization of tau from axons to dendritic spines, resulting in decreased expression of AMPA receptors and LTP deficits; preventing tau phosphorylation prevented mislocalization and rescued LTP deficits [155].

A particularly interesting topic of late, however, is the notion that tau mediates or enables $A \beta$ 's excitotoxic effects [e.g., 14, 158]. Tau necessity was first shown in 2002 when primary cultured neurons from tau knockout mice were shown to be resistant to $A \beta$ exposure [159], but it was not until 2007 that this effect was confirmed in vivo by crossing APP transgenic mice with tau knockout mice [158]. Since this time, NMDARs, or more specifically the NR2B-PSD95-Fyn complex within dendritic spines, has been identified as a convergence point for tau, glutamate, and $\mathrm{A} \beta[7,160]$.

Fyn is a tyrosine kinase that phosphorylates the NR2B receptor subunit Tyr1472, thereby stabilizing its interaction with PSD95, a scaffolding protein in dendritic spines [161]. Stabilization of the NR2B:PSD95 complex enhances the glutamatergic excitotoxicity induced by $A \beta$ [14]. Overexpression of Fyn exacerbates $A \beta$-related cognitive deficits and premature lethality $[162,163]$, whereas Fyn ablation protects against $A \beta$ toxicity [163]. Tau mediates this process via its binding and transport of Fyn to dendritic spines [14]. Tau reductions, or expression of tau fragments that cannot transport Fyn to dendritic spines, prevent the memory deficits and network excitability caused by $\mathrm{A} \beta[14,160]$, an effect attributed to a reduction in postsynaptic targeting of Fyn [14].

Until recently, tau was believed to be restricted to axons under physiological conditions, and to mislocalize to the somatodendritic regions only during pathological events [155]. However, more recent evidence suggests physiological tau does localize to dendritic spines [14, 164] where it binds not only Fyn but also the PSD95NMDA receptor complex [164]. This binding, however, is phosphorylation dependent; NMDA receptor activation increases tau phosphorylation of tau, at GSK3ß-dependent sites - PHF-1, AT8, and AT180 leading to a decrease in tau's affinity for PSD95 and an increase in tau's interaction with Fyn. Tau's increased affinity for Fyn is believed to lead to a transient increase in synaptic Fyn and hence to a temporary increase in NMDA receptor activation before tau-Fyn leaves the PSD95-NMDA receptor complex [164].

Tau phosphorylation also increases NMDA receptor transmission and facilitation of LTD [164]. Noteworthy 
is the finding that NMDA receptor-dependent phosphorylation of tau is transient, whereas tau phosphorylation after 5 days of $A \beta$ exposure is not [164]. Because tau phosphorylation increases facilitation of LTD [164] and LTD leads to AMPA receptor endocytosis [165], this prolonged tau phosphorylation observed after A $\beta$ exposure might explain the endocytosis of AMPA receptors induced by $A \beta$ oligomers [166], though this has yet to be definitively shown.

Although the investigation into the role of tau in glutamate excitotoxicity is a relatively nascent field, it warrants attention in that tau likely serves as a mediator of $A \beta$-induced neuronal death [7, 14, 106, 167-169] and can induce synaptic dysfunction independently (see [157] for review). Similarly, it is becoming clear that extrasynaptic NR2B receptors play a prominent role in mediating this interaction between $\mathrm{A} \beta$ and tau $[7,14$, 164]. Recent work suggests $A \beta$-induced neuronal death, as well as tau phosphorylation via GSK3 $\beta$, is mediated by NR2B- but not NR2A- containing receptors [7]. Blockade of NR2B receptors, or removal of tau, prevents $A \beta$-induced neuronal death [7]. However, tau may not be necessary for all of $A \beta$ 's effects; $A \beta$-induced dendritic spine loss occurs via a pathway involving NR2Acontaining NMDARs and is tau-independent [7]. Thus, further elucidation of tau-dependent and tau-independent pathways is needed, as well as a better understanding of which NMDA receptors mediate the various pathological effects produced by $A \beta$.

\section{Future Directions}

Though the role of the tripartite glutamatergic synapse in the pathophysiology of Alzheimer's disease has become much clearer in recent years, several questions still remain. Whether the network dysfunction characteristic of $A D$ is due in part to an $A \beta$-mediated spread of glutamate from one synaptic domain to the next is still unknown. Reports that early $\mathrm{A} \beta$ deposition occurs preferentially in regions of high neuronal activity [170] and that secretion of $A \beta$ is driven by synaptic activity [e.g., 171] suggests diffusion of extracellular glutamate to neighboring synapses could facilitate the spread of $A \beta$ pathology. Similarly, recent work suggests presynaptic glutamate release is sufficient to drive tau release into the extracellular space [172]. Thus, glutamate-mediated exocytosis of tau may indicate one mechanism for the trans-synaptic spread of tau pathology associated with synaptic activity. A better understanding of the role of glutamate in the trans-synaptic spread of pathology could facilitate our understanding of risk factors for AD. For example, aging, the greatest known risk factor for $\mathrm{AD}$, is associated with a decline in glutamate transporters and uptake [173, 174], leading to higher levels of extracellular glutamate [175]. This age-related increase in extracellular glutamate results in greater activation of extrasynaptic NMDARs [176, 177] and could potentially be permissive for the spread of $A \beta$ and tau pathology through vulnerable networks.

\section{Conclusions}

The studies reviewed here indicate the glutamatergic system, particularly E-NMDARs, play a critical role in the synaptic dysfunction and neuronal death triggered by both $A \beta$ and tau. Improving our understanding of these alterations will hopefully lead to the development of therapeutics needed to prevent or attenuate these pathological processes. A greater understanding of the role of excitotoxicity in the pathogenesis of AD would not only inform therapeutic design for AD but also a host of other acute and chronic diseases with excitotoxicity as a core feature.

\section{Acknowledgements}

The project described was supported by the National Institute of General Medical Sciences, U54GM104942, and the Alzheimer's Association, NIRG-12-242187 (MNR). The content is solely the responsibility of the authors and does not necessarily represent the official views of the NIH or Alzheimer's Association.

\section{References}

[1] Alzheimer's Association, Thies W, Bleiler L (2011). 2011 Alzheimer's disease facts and figures. Alzheimer's and Dementia, 7: 208-244

[2] Thies W, Bleiler L (2013). 2013 Alzheimer's disease facts and figures. Alzheimer's \& dementia, 9: 208-245

[3] Serrano-Pozo A, Frosch MP, Masliah E, Hyman BT (2011). Neuropathological alterations in Alzheimer disease. Cold Spring Harbor perspectives in medicine, 1: a006189

[4] Terry RD, Masliah E, Salmon DP, Butters N, DeTeresa R, Hill R, et al. (1991). Physical basis of cognitive alterations in Alzheimer's disease: synapse loss is the major correlate of cognitive impairment. Annals of neurology, 30: 572-580

[5] Mucke L, Masliah E, Yu GQ, Mallory M, Rockenstein EM, Tatsuno G, et al. (2000). High-level neuronal expression of abeta 1-42 in wild-type human amyloid protein precursor transgenic mice: synaptotoxicity without plaque formation. The Journal of neuroscience, 20: 4050-4058

[6] Hsia AY, Masliah E, McConlogue L, Yu GQ, Tatsuno G, Hu K, et al. (1999). Plaque-independent disruption 
of neural circuits in Alzheimer's disease mouse models. Proceedings of the National Academy of Sciences of the United States of America, 96: 3228-3233

Tackenberg C, Grinschgl S, Trutzel A, Santuccione AC, Frey MC, Konietzko U, et al. (2013). NMDA receptor subunit composition determines beta-amyloidinduced neurodegeneration and synaptic loss. Cell Death and Disease, 4: 1-10

[8] Curtis DR, Phillis JW, Watkins JC (1960). The chemical excitation of spinal neurones by certain acidic amino acids. The Journal of physiology, 150: 656-682

[9] Sheldon AL, Robinson MB (2007). The role of glutamate transporters in neurodegenerative diseases and potential opportunities for intervention. Neurochemistry international, 51: 333-355

[10] Bliss TV, Collingridge GL (1993). A synaptic model of memory: long-term potentiation in the hippocampus. Nature, 361: 31-39

[11] Bliss TV, Lomo T (1973). Long-lasting potentiation of synaptic transmission in the dentate area of the anaesthetized rabbit following stimulation of the perforant path. The Journal of physiology, 232: 331356

[12] Bliss TV, Gardner-Medwin AR (1973). Long-lasting potentiation of synaptic transmission in the dentate area of the unanaestetized rabbit following stimulation of the perforant path. The Journal of physiology, 232: 357-374

[13] Olney JW, Price MT, Samson L, Labruyere J (1986). The role of specific ions in glutamate neurotoxicity. Neuroscience letters, 65: 65-71

[14] Ittner LM, Ke YD, Delerue F, Bi M, Gladbach A, van Eersel J, et al. (2010). Dendritic function of tau mediates amyloid-beta toxicity in Alzheimer's disease mouse models. Cell, 142: 387-397

[15] Hardingham GE, Bading H (2010). Synaptic versus extrasynaptic NMDA receptor signalling: implications for neurodegenerative disorders. Nat Rev Neurosci., 11: 682-696. Epub 2010 Sep 2015.

[16] Hardingham GE, Fukunaga Y, Bading H (2002). Extrasynaptic NMDARs oppose synaptic NMDARs by triggering CREB shut-off and cell death pathways. Nature neuroscience, 5: 405-414

[17] Parpura V, Basarsky TA, Liu F, Jeftinija K, Jeftinija S, Haydon PG (1994). Glutamate-mediated astrocyteneuron signalling. Nature, 369: 744-747

[18] Krebs HA, Johnson WA (1937). Metabolism of ketonic acids in animal tissues. Biochem J, 31: 645-660

[19] Norenberg MD, Martinez-Hernandez A (1979). Fine structural localization of glutamine synthetase in astrocytes of rat brain. Brain research, 161: 303-310

[20] Li D, Herault K, Silm K, Evrard A, Wojcik S, Oheim M, et al. (2013). Lack of evidence for vesicular glutamate transporter expression in mouse astrocytes. The Journal of neuroscience 33: 4434-4455

[21] Bollmann JH, Sakmann B, Borst JG (2000). Calcium sensitivity of glutamate release in a calyx-type terminal. Science (New York, N.Y.), 289: 953-957
[22] Sudhof TC (2004). The synaptic vesicle cycle. Annu Rev Neurosci, 27: 509-547

[23] Takamori S, Rhee JS, Rosenmund C, Jahn R (2000). Identification of a vesicular glutamate transporter that defines a glutamatergic phenotype in neurons. Nature, 407: 189-194

[24] Montana V, Ni Y, Sunjara V, Hua X, Parpura V (2004). Vesicular glutamate transporter-dependent glutamate release from astrocytes. The Journal of neuroscience, 24: $2633-2642$

[25] Bannai S (1986). Exchange of cystine and glutamate across plasma membrane of human fibroblasts. The Journal of biological chemistry, 261: 2256-2263

[26] Baker DA, Xi ZX, Shen H, Swanson CJ, Kalivas PW (2002). The origin and neuronal function of in vivo nonsynaptic glutamate. The Journal of neuroscience, 22: $9134-9141$

[27] Hollmann M, O'Shea-Greenfield A, Rogers SW, Heinemann S (1989). Cloning by functional expression of a member of the glutamate receptor family. Nature, 342: 643-648

[28] Sugiyama H, Ito I, Hirono C (1987). A new type of glutamate receptor linked to inositol phospholipid metabolism. Nature, 325: 531-533

[29] Nakanishi S (1992). Molecular diversity of glutamate receptors and implications for brain function. Science (New York, N.Y.), 258: 597-603

[30] Traynelis SF, Wollmuth LP, McBain CJ, Menniti FS, Vance KM, Ogden KK, et al. (2010). Glutamate receptor ion channels: structure, regulation, and function. Pharmacological reviews, 62: 405-496

[31] Curtis DR, Watkins JC (1963). Acidic amino acids with strong excitatory actions on mammalian neurones. The Journal of physiology, 166: 1-14

[32] Safferling M, Tichelaar W, Kummerle G, Jouppila A, Kuusinen A, Keinanen K, et al. (2001). First images of a glutamate receptor ion channel: oligomeric state and molecular dimensions of GluRB homomers. Biochemistry, 40: 13948-13953

[33] Tichelaar W, Safferling M, Keinanen K, Stark H, Madden DR (2004). The Three-dimensional Structure of an Ionotropic Glutamate Receptor Reveals a Dimerof-dimers Assembly. Journal of molecular biology, 344: 435-442

[34] Nakagawa T, Cheng Y, Ramm E, Sheng M, Walz T (2005). Structure and different conformational states of native AMPA receptor complexes. Nature, 433: 545549

[35] Sobolevsky AI, Rosconi MP, Gouaux E (2009). X-ray structure, symmetry and mechanism of an AMPAsubtype glutamate receptor. Nature, 462: 745-756

[36] Laube B, Kuhse J, Betz H (1998). Evidence for a tetrameric structure of recombinant NMDA receptors. The Journal of neuroscience, 18: 2954-2961

[37] Tang CM, Dichter M, Morad M (1989). Quisqualate activates a rapidly inactivating high conductance ionic channel in hippocampal neurons. Science (New York, N.Y.), 243: 1474-1477 
[38] Chittajallu R, Vignes M, Dev KK, Barnes JM, Collingridge GL, Henley JM (1996). Regulation of glutamate release by presynaptic kainate receptors in the hippocampus. Nature, 379: 78-81

[39] Mayer ML, Westbrook GL, Guthrie PB (1984). Voltage-dependent block by $\mathrm{Mg} 2+$ of NMDA responses in spinal cord neurones. Nature, 309: 261263

[40] Lester RA, Clements JD, Westbrook GL, Jahr CE (1990). Channel kinetics determine the time course of NMDA receptor-mediated synaptic currents. Nature, 346: 565-567

[41] Laube B, Hirai H, Sturgess M, Betz H, Kuhse J (1997). Molecular determinants of agonist discrimination by NMDA receptor subunits: analysis of the glutamate binding site on the NR2B subunit. Neuron, 18: 493-503

[42] Panatier A, Theodosis DT, Mothet JP, Touquet B, Pollegioni L, Poulain DA, et al. (2006). Glia-derived D-serine controls NMDA receptor activity and synaptic memory. Cell, 125: 775-784

[43] Kleckner NW, Dingledine R (1988). Requirement for glycine in activation of NMDA-receptors expressed in Xenopus oocytes. Science (New York, N.Y.), 241: 835837

[44] Henneberger C, Papouin T, Oliet SH, Rusakov DA (2010). Long-term potentiation depends on release of D-serine from astrocytes. Nature, 463: 232-236

[45] Jahr CE, Stevens CF (1993). Calcium permeability of the N-methyl-D-aspartate receptor channel in hippocampal neurons in culture. Proceedings of the National Academy of Sciences of the United States of America, 90: 11573-11577

[46] Dingledine R (1983). N-methyl aspartate activates voltage-dependent calcium conductance in rat hippocampal pyramidal cells. The Journal of physiology, 343: 385-405

[47] MacDermott AB, Mayer ML, Westbrook GL, Smith SJ, Barker JL (1986). NMDA-receptor activation increases cytoplasmic calcium concentration in cultured spinal cord neurones. Nature, 321: 519-522

[48] Choi DW (1987). Ionic dependence of glutamate neurotoxicity. The Journal of neuroscience, 7: 369-379

[49] Choi DW, Koh JY, Peters S (1988). Pharmacology of glutamate neurotoxicity in cortical cell culture: attenuation by NMDA antagonists. The Journal of neuroscience: the official journal of the Society for Neuroscience, 8: 185-196

[50] Choi DW, Maulucci-Gedde M, Kriegstein AR (1987). Glutamate neurotoxicity in cortical cell culture. The Journal of neuroscience: the official journal of the Society for Neuroscience, 7: 357-368

[51] Kunishima N, Shimada Y, Tsuji Y, Sato T, Yamamoto M, Kumasaka T, et al. (2000). Structural basis of glutamate recognition by a dimeric metabotropic glutamate receptor. Nature, 407: 971-977

[52] Houamed KM, Kuijper JL, Gilbert TL, Haldeman BA, O'Hara PJ, Mulvihill ER, et al. (1991). Cloning, expression, and gene structure of a $G$ protein-coupled glutamate receptor from rat brain. Science (New York, N.Y.), 252: 1318-1321

[53] Masu M, Tanabe Y, Tsuchida K, Shigemoto R, Nakanishi S (1991). Sequence and expression of a metabotropic glutamate receptor. Nature, 349: 760-765

[54] Nicoletti F, Wroblewski JT, Fadda E, Costa E (1988). Pertussis toxin inhibits signal transduction at a specific metabolotropic glutamate receptor in primary cultures of cerebellar granule cells. Neuropharmacology, 27: 551-556

[55] Nicoletti F, Meek JL, Iadarola MJ, Chuang DM, Roth BL, Costa E (1986). Coupling of inositol phospholipid metabolism with excitatory amino acid recognition sites in rat hippocampus. Journal of neurochemistry, 46: $40-46$

[56] Abe T, Sugihara H, Nawa H, Shigemoto R, Mizuno N, Nakanishi S (1992). Molecular characterization of a novel metabotropic glutamate receptor mGluR5 coupled to inositol phosphate/Ca2+ signal transduction. The Journal of biological chemistry, 267: 13361-13368

[57] Nakajima $Y$, Iwakabe $H$, Akazawa C, Nawa H, Shigemoto R, Mizuno N, et al. (1993). Molecular characterization of a novel retinal metabotropic glutamate receptor mGluR6 with a high agonist selectivity for L-2-amino-4-phosphonobutyrate. The Journal of biological chemistry, 268: 11868-11873

[58] Okamoto N, Hori S, Akazawa C, Hayashi Y, Shigemoto R, Mizuno N, et al. (1994). Molecular characterization of a new metabotropic glutamate receptor mGluR7 coupled to inhibitory cyclic AMP signal transduction. The Journal of biological chemistry, 269: 1231-1236

[59] Tanabe $Y$, Masu M, Ishii T, Shigemoto R, Nakanishi S (1992). A family of metabotropic glutamate receptors. Neuron, 8: 169-179

[60] Tanabe Y, Nomura A, Masu M, Shigemoto R, Mizuno N, Nakanishi S (1993). Signal transduction, pharmacological properties, and expression patterns of two rat metabotropic glutamate receptors, mGluR3 and mGluR4. The Journal of neuroscience, 13: 1372-1378

[61] Palop JJ, Chin J, Mucke L (2006). A network dysfunction perspective on neurodegenerative diseases. Nature, 443: 768-773

[62] Danbolt NC (2001). Glutamate uptake. Prog Neurobiol, 65: 1-105

[63] Lehre KP, Levy LM, Ottersen OP, Storm-Mathisen J, Danbolt NC (1995). Differential expression of two glial glutamate transporters in the rat brain: quantitative and immunocytochemical observations. The Journal of neuroscience, 15: 1835-1853

[64] Lehre KP, Davanger S, Danbolt NC (1997). Localization of the glutamate transporter protein GLAST in rat retina. Brain research, 744: 129-137

[65] Crino PB, Jin H, Shumate MD, Robinson MB, Coulter DA, Brooks-Kayal AR (2002). Increased expression of the neuronal glutamate transporter (EAAT3/EAAC1) in hippocampal and neocortical epilepsy. Epilepsia, 43: 211-218 
[66] Kanai Y, Hediger MA (1992). Primary structure and functional characterization of a high-affinity glutamate transporter. Nature, 360: 467-471

[67] Haugeto O, Ullensvang K, Levy LM, Chaudhry FA, Honore T, Nielsen M, et al. (1996). Brain glutamate transporter proteins form homomultimers. The Journal of biological chemistry, 271: 27715-27722

[68] Arriza JL, Eliasof S, Kavanaugh MP, Amara SG (1997). Excitatory amino acid transporter 5, a retinal glutamate transporter coupled to a chloride conductance. Proceedings of the National Academy of Sciences of the United States of America, 94: 41554160

[69] Nilsson A, Duan J, Mo-Boquist LL, Benedikz E, Sundstrom E (2007). Characterisation of the human NMDA receptor subunit NR3A glycine binding site. Neuropharmacology, 52: 1151-1159

[70] Kutsuwada T, Kashiwabuchi N, Mori H, Sakimura K, Kushiya E, Araki K, et al. (1992). Molecular diversity of the NMDA receptor channel. Nature, 358: 36-41

[71] Al-Hallaq RA, Jarabek BR, Fu Z, Vicini S, Wolfe BB, Yasuda RP (2002). Association of NR3A with the Nmethyl-D-aspartate receptor NR1 and NR2 subunits. Molecular pharmacology, 62: 1119-1127

[72] Fukaya M, Hayashi Y, Watanabe M (2005). NR2 to NR3B subunit switchover of NMDA receptors in early postnatal motoneurons. The European journal of neuroscience, 21: 1432-1436

[73] Cao X, Cui Z, Feng R, Tang YP, Qin Z, Mei B, et al. (2007). Maintenance of superior learning and memory function in NR2B transgenic mice during ageing. The European journal of neuroscience, 25: 1815-1822

[74] von Engelhardt J, Coserea I, Pawlak V, Fuchs EC, Kohr G, Seeburg PH, et al. (2007). Excitotoxicity in vitro by NR2A- and NR2B-containing NMDA receptors. Neuropharmacology, 53: 10-17

[75] Braak H, Braak E (1998). Argyrophilic grain disease: frequency of occurrence in different age categories and neuropathological diagnostic criteria. Journal of neural transmission, 105: 801-819

[76] Du AT, Schuff N, Kramer JH, Ganzer S, Zhu XP, Jagust WJ, et al. (2004). Higher atrophy rate of entorhinal cortex than hippocampus in AD. Neurology, 62: $422-427$

[77] van de Pol LA, van der Flier WM, Korf ES, Fox NC, Barkhof F, Scheltens P (2007). Baseline predictors of rates of hippocampal atrophy in mild cognitive impairment. Neurology, 69: 1491-1497

[78] Groc L, Bard L, Choquet D (2009). Surface trafficking of N-methyl-d-aspartate receptors: Physiological and pathological perspectives. Neuroscience, 158: 4-18

[79] Newpher TM, Ehlers MD (2009). Spine microdomains for postsynaptic signaling and plasticity. Trends Cell Biol., 19: 218-227. Epub 2009 Mar 2028.

[80] Petralia RS, Sans N, Wang YX, Wenthold RJ (2005). Ontogeny of postsynaptic density proteins at glutamatergic synapses. Mol Cell Neurosci., 29: 436452.
[81] Groc L, Choquet D (2006). AMPA and NMDA glutamate receptor trafficking: multiple roads for reaching and leaving the synapse. Cell Tissue Res., 326: 423-438

[82] Petralia RS, Wang YX, Hua F, Yi Z, Zhou A, Ge L, et al. (2010). Organization of NMDA receptors at extrasynaptic locations. Neuroscience, 167: 68-87.

[83] Liu Y, Wong TP, Aarts M, Rooyakkers A, Liu L, Lai TW, et al. (2007). NMDA receptor subunits have differential roles in mediating excitotoxic neuronal death both in vitro and in vivo. J Neurosci, 27: 28462857.

[84] Mothet J-P, Parent AT, Wolosker H, Brady RO, Linden DJ, Ferris CD, et al. (2000). d-Serine is an endogenous ligand for the glycine site of the N-methyl-d-aspartate receptor. Proceedings of the National Academy of Sciences, 97: 4926-4931

[85] Papouin T, Ladepeche L, Ruel J, Sacchi S, Labasque M, Hanini M, et al. (2012). Synaptic and extrasynaptic NMDA receptors are gated by different endogenous coagonists. Cell, 150: 633-646

[86] Matsui T, Sekiguchi M, Hashimoto A, Tomita U, Nishikawa T, Wada K (1995). Functional comparison of D-serine and glycine in rodents: the effect on cloned NMDA receptors and the extracellular concentration. Journal of neurochemistry, 65: 454-458

[87] Henneberger C, Bard L, King C, Jennings A, Rusakov DA (2013). NMDA receptor activation: two targets for two co-agonists. Neurochemical research, 38: 11561162

[88] Gray John A, Nicoll Roger A Thinking Outside the Synapse: Glycine at Extrasynaptic NMDA Receptors. Cell, 150: 455-456

[89] Brightwell JJ, Gallagher M, Colombo PJ (2004). Hippocampal CREB1 but not CREB2 is decreased in aged rats with spatial memory impairments. Neurobiol Learn Mem, 81: 19-26

[90] Deisseroth K, Bito H, Tsien RW (1996). Signaling from synapse to nucleus: postsynaptic CREB phosphorylation during multiple forms of hippocampal synaptic plasticity. Neuron, 16: 89-101.

[91] Impey S, Smith DM, Obrietan K, Donahue R, Wade C, Storm DR (1998). Stimulation of cAMP response element (CRE)-mediated transcription during contextual learning. Nat Neurosci, 1: 595-601.

[92] Papadia S, Soriano FX, Leveille F, Martel MA, Dakin KA, Hansen HH, et al. (2008). Synaptic NMDA receptor activity boosts intrinsic antioxidant defenses. Nat Neurosci, 11: 476-487

[93] Acheson A, Conover JC, Fandl JP, DeChiara TM, Russell M, Thadani A, et al. (1995). A BDNF autocrine loop in adult sensory neurons prevents cell death. Nature, 374: 450-453

[94] Al-Mubarak B, Soriano FX, Hardingham GE (2009). Synaptic NMDAR activity suppresses FOXO1 expression via a cis-acting FOXO binding site: FOXO1 is a FOXO target gene. Channels (Austin, Tex.), 3: 233-238 
[95] Mulholland PJ, Luong NT, Woodward JJ, Chandler LJ (2008). Brain-derived neurotrophic factor activation of extracellular signal-regulated kinase is autonomous from the dominant extrasynaptic NMDA receptor extracellular signal-regulated kinase shutoff pathway. Neuroscience, 151: 419-427

[96] Schafe GE, Atkins CM, Swank MW, Bauer EP, Sweatt JD, LeDoux JE (2000). Activation of ERK/MAP kinase in the amygdala is required for memory consolidation of pavlovian fear conditioning. The Journal of neuroscience, 20: 8177-8187

[97] Dick O, Bading H (2010). Synaptic activity and nuclear calcium signaling protect hippocampal neurons from death signal-associated nuclear translocation of FoxO3a induced by extrasynaptic N-methyl-Daspartate receptors. The Journal of biological chemistry, 285: 19354-19361

[98] Xu J, Kurup P, Zhang Y, Goebel-Goody SM, Wu PH, Hawasli AH, et al. (2009). Extrasynaptic NMDA receptors couple preferentially to excitotoxicity via calpain-mediated cleavage of STEP. The Journal of neuroscience, 29: 9330-9343

[99] Qi X, Tang J, Pramanik R, Schultz RM, Shirasawa S, Sasazuki T, et al. (2004). p38 MAPK activation selectively induces cell death in K-ras-mutated human colon cancer cells through regulation of vitamin D receptor. The Journal of biological chemistry, 279: 22138-22144

[100] Dunah AW, Sirianni AC, Fienberg AA, Bastia E, Schwarzschild MA, Standaert DG (2004). Dopamine D1-dependent trafficking of striatal N-methyl-Daspartate glutamate receptors requires Fyn protein tyrosine kinase but not DARPP-32. Molecular pharmacology, 65: 121-129

[101] Hallett PJ, Spoelgen R, Hyman BT, Standaert DG, Dunah AW (2006). Dopamine D1 activation potentiates striatal NMDA receptors by tyrosine phosphorylation-dependent subunit trafficking. The Journal of neuroscience, 26: 4690-4700

[102] Snyder EM, Nong Y, Almeida CG, Paul S, Moran T, Choi EY, et al. (2005). Regulation of NMDA receptor trafficking by amyloid-beta. Nature neuroscience, 8 : 1051-1058

[103] Allyson J, Dontigny E, Auberson Y, Cyr M, Massicotte G (2010). Blockade of NR2A-containing NMDA receptors induces Tau phosphorylation in rat hippocampal slices. Neural Plast., 2010: 340168. Epub 342010 May 340120.

[104] Amadoro G, Ciotti MT, Costanzi M, Cestari V, Calissano P, Canu N (2006). NMDA receptor mediates tau-induced neurotoxicity by calpain and ERK/MAPK activation. Proceedings of the National Academy of Sciences of the United States of America, 103: 28922897

[105] Xia P, Chen HS, Zhang D, Lipton SA (2010). Memantine preferentially blocks extrasynaptic over synaptic NMDA receptor currents in hippocampal autapses. J Neurosci, 30: 11246-11250.
[106] Song MS, Rauw G, Baker GB, Kar S (2008). Memantine protects rat cortical cultured neurons against beta-amyloid-induced toxicity by attenuating tau phosphorylation. The European journal of neuroscience, 28: 1989-2002

[107] Okamoto S, Pouladi MA, Talantova M, Yao D, Xia P, Ehrnhoefer DE, et al. (2009). Balance between synaptic versus extrasynaptic NMDA receptor activity influences inclusions and neurotoxicity of mutant huntingtin. Nat Med., 15: 1407-1413. Epub 2009 Nov 1415.

[108] Parsons CG, Stoffler A, Danysz W (2007). Memantine: a NMDA receptor antagonist that improves memory by restoration of homeostasis in the glutamatergic system-too little activation is bad, too much is even worse. Neuropharmacology, 53: 699-723

[109] Masters CL, Beyreuther K (1987). Neuronal origin of cerebral amyloidogenic proteins: their role in Alzheimer's disease and unconventional virus diseases of the nervous system. Ciba Foundation symposium, 126: 49-64

[110] Kang J, Lemaire HG, Unterbeck A, Salbaum JM, Masters CL, Grzeschik KH, et al. (1987). The precursor of Alzheimer's disease amyloid A4 protein resembles a cell-surface receptor. Nature, 325: 733-736

[111] Glenner GG, Murphy MA (1989). Amyloidosis of the nervous system. Journal of the neurological sciences, 94: 1-28

[112] Palmert MR, Podlisny MB, Witker DS, Oltersdorf T, Younkin LH, Selkoe DJ, et al. (1989). The betaamyloid protein precursor of Alzheimer disease has soluble derivatives found in human brain and cerebrospinal fluid. Proceedings of the National Academy of Sciences of the United States of America, 86: 6338-6342

[113] Joachim CL, Selkoe DJ (1992). The seminal role of beta-amyloid in the pathogenesis of Alzheimer disease. Alzheimer disease and associated disorders, 6: 7-34

[114] Hardy J, Allsop D (1991). Amyloid deposition as the central event in the aetiology of Alzheimer's disease. Trends Pharmacol Sci, 12: 383-388

[115] Barghorn S, Nimmrich V, Striebinger A, Krantz C, Keller P, Janson B, et al. (2005). Globular amyloid beta-peptide oligomer - a homogenous and stable neuropathological protein in Alzheimer's disease. Journal of neurochemistry, 95: 834-847

[116] Gong Y, Chang L, Viola KL, Lacor PN, Lambert MP, Finch CE, et al. (2003). Alzheimer's disease-affected brain: presence of oligomeric A beta ligands (ADDLs) suggests a molecular basis for reversible memory loss. Proceedings of the National Academy of Sciences of the United States of America, 100: 10417-10422

[117] Lacor PN, Buniel MC, Furlow PW, Clemente AS, Velasco PT, Wood M, et al. (2007). Abeta oligomerinduced aberrations in synapse composition, shape, and density provide a molecular basis for loss of connectivity in Alzheimer's disease. J Neurosci, 27: 796-807 
[118] Demuro A, Mina E, Kayed R, Milton SC, Parker I, Glabe CG (2005). Calcium dysregulation and membrane disruption as a ubiquitous neurotoxic mechanism of soluble amyloid oligomers. The Journal of biological chemistry, 280: 17294-17300

[119] Roselli F, Tirard M, Lu J, Hutzler P, Lamberti P, Livrea P, et al. (2005). Soluble beta-amyloid1-40 induces NMDA-dependent degradation of postsynaptic density-95 at glutamatergic synapses. The Journal of neuroscience, 25: 11061-11070

[120] Christensen DZ, Kraus SL, Flohr A, Cotel MC, Wirths O, Bayer TA (2008). Transient intraneuronal A beta rather than extracellular plaque pathology correlates with neuron loss in the frontal cortex of APP/PS1KI mice. Acta neuropathologica, 116: 647-655

[121] Walsh DM, Klyubin I, Fadeeva JV, Cullen WK, Anwyl R, Wolfe MS, et al. (2002). Naturally secreted oligomers of amyloid beta protein potently inhibit hippocampal long-term potentiation in vivo. Nature, 416: 535-539

[122] Kamenetz F, Tomita T, Hsieh H, Seabrook G, Borchelt D, Iwatsubo T, et al. (2003). APP processing and synaptic function. Neuron, 37: 925-937

[123] Shankar GM, Bloodgood BL, Townsend M, Walsh DM, Selkoe DJ, Sabatini BL (2007). Natural oligomers of the Alzheimer amyloid-beta protein induce reversible synapse loss by modulating an NMDA-type glutamate receptor-dependent signaling pathway. The Journal of neuroscience, 27: 2866-2875

[124] Li S, Hong S, Shepardson NE, Walsh DM, Shankar GM, Selkoe D (2009). Soluble oligomers of amyloid Beta protein facilitate hippocampal long-term depression by disrupting neuronal glutamate uptake. Neuron, 62: 788-801

[125] Arias C, Arrieta I, Tapia R (1995). beta-Amyloid peptide fragment 25-35 potentiates the calciumdependent release of excitatory amino acids from depolarized hippocampal slices. Journal of neuroscience research, 41: 561-566

[126] Brito-Moreira J, Paula-Lima AC, Bomfim TR, Oliveira FB, Sepulveda FJ, De Mello FG, et al. (2011). Abeta oligomers induce glutamate release from hippocampal neurons. Current Alzheimer research, 8: 552-562

[127] Pirttimaki TM, Codadu NK, Awni A, Pratik P, Nagel DA, Hill EJ, et al. (2013). alpha7 Nicotinic receptormediated astrocytic gliotransmitter release: Abeta effects in a preclinical Alzheimer's mouse model. PloS one, 8: e81828

[128] Talantova M, Sanz-Blasco S, Zhang X, Xia P, Akhtar MW, Okamoto S, et al. (2013). Abeta induces astrocytic glutamate release, extrasynaptic NMDA receptor activation, and synaptic loss. Proceedings of the National Academy of Sciences of the United States of America, 110: E2518-2527

[129] Noda M, Nakanishi H, Akaike N (1999). Glutamate release from microglia via glutamate transporter is enhanced by amyloid-beta peptide. Neuroscience, 92: 1465-1474
[130] Rush T, Buisson A (2014). Reciprocal disruption of neuronal signaling and Abeta production mediated by extrasynaptic NMDA receptors: a downward spiral. Cell and tissue research,

[131] Parpura-Gill A, Beitz D, Uemura E (1997). The inhibitory effects of beta-amyloid on glutamate and glucose uptakes by cultured astrocytes. Brain research, 754: 65-71

[132] Matos M, Augusto E, Oliveira CR, Agostinho P (2008). Amyloid-beta peptide decreases glutamate uptake in cultured astrocytes: involvement of oxidative stress and mitogen-activated protein kinase cascades. Neuroscience, 156: 898-910

[133] Scimemi A, Meabon JS, Woltjer RL, Sullivan JM, Diamond JS, Cook DG (2013). Amyloid-beta1-42 slows clearance of synaptically released glutamate by mislocalizing astrocytic GLT-1. The Journal of neuroscience, 33: 5312-5318

[134] Harris ME, Wang Y, Pedigo NW, Jr., Hensley K, Butterfield DA, Carney JM (1996). Amyloid beta peptide (25-35) inhibits $\mathrm{Na+-dependent} \mathrm{glutamate}$ uptake in rat hippocampal astrocyte cultures. Journal of neurochemistry, 67: 277-286

[135] Bicca MA, Figueiredo CP, Piermartiri TC, Meotti FC, Bouzon ZL, Tasca CI, et al. (2011). The selective and competitive N-methyl-D-aspartate receptor antagonist, (-)-6-phosphonomethyl-deca-hydroisoquinoline-3carboxylic acid, prevents synaptic toxicity induced by amyloid-beta in mice. Neuroscience, 192: 631-641

[136] Mookherjee P, Green PS, Watson GS, Marques MA, Tanaka K, Meeker KD, et al. (2011). GLT-1 loss accelerates cognitive deficit onset in an Alzheimer's disease animal model. Journal of Alzheimer's disease, 26: $447-455$

[137] Woltjer RL, Duerson K, Fullmer JM, Mookherjee P, Ryan AM, Montine TJ, et al. (2010). Aberrant detergent-insoluble excitatory amino acid transporter 2 accumulates in Alzheimer disease. Journal of neuropathology and experimental neurology, 69: 667676

[138] Pihlaja R, Koistinaho J, Malm T, Sikkila H, Vainio S, Koistinaho M (2008). Transplanted astrocytes internalize deposited beta-amyloid peptides in a transgenic mouse model of Alzheimer's disease. Glia, 56: $154-163$

[139] Wyss-Coray T, Loike JD, Brionne TC, Lu E, Anankov R, Yan F, et al. (2003). Adult mouse astrocytes degrade amyloid-beta in vitro and in situ. Nature medicine, 9: 453-457

[140] Yamamoto N, Arima H, Naruse K, Kasahara R, Taniura H, Hirate H, et al. (2013). Ketamine reduces amyloid $\beta$-protein degradation by suppressing neprilysin expression in primary cultured astrocytes. Neuroscience letters, 545: 54-58

[141] Apelt J, Ach K, Schliebs R (2003). Aging-related down-regulation of neprilysin, a putative $\beta$-amyloiddegrading enzyme, in transgenic Tg2576 Alzheimerlike mouse brain is accompanied by an astroglial 
upregulation in the vicinity of $\beta$-amyloid plaques. Neuroscience letters, 339: 183-186

[142] Shelat PB, Chalimoniuk M, Wang JH, Strosznajder JB, Lee JC, Sun AY, et al. (2008). Amyloid beta peptide and NMDA induce ROS from NADPH oxidase and AA release from cytosolic phospholipase A2 in cortical neurons. Journal of neurochemistry, 106: 45-55

[143] Rammes G, Hasenjager A, Sroka-Saidi K, Deussing JM, Parsons CG (2011). Therapeutic significance of NR2B-containing NMDA receptors and mGluR5 metabotropic glutamate receptors in mediating the synaptotoxic effects of beta-amyloid oligomers on long-term potentiation (LTP) in murine hippocampal slices. Neuropharmacology, 60: 982-990

[144] Nakagami Y, Oda T (2002). Glutamate exacerbates amyloid beta1-42-induced impairment of long-term potentiation in rat hippocampal slices. Japanese journal of pharmacology, 88: 223-226

[145] Li S, Jin M, Koeglsperger T, Shepardson NE, Shankar GM, Selkoe DJ (2011). Soluble Abeta oligomers inhibit long-term potentiation through a mechanism involving excessive activation of extrasynaptic NR2Bcontaining NMDA receptors. The Journal of neuroscience, 31: 6627-6638

[146] Wang Q, Walsh DM, Rowan MJ, Selkoe DJ, Anwyl R (2004). Block of long-term potentiation by naturally secreted and synthetic amyloid beta-peptide in hippocampal slices is mediated via activation of the kinases c-Jun N-terminal kinase, cyclin-dependent kinase 5 , and p38 mitogen-activated protein kinase as well as metabotropic glutamate receptor type 5 . The Journal of neuroscience, 24: 3370-3378

[147] Shankar GM, Li S, Mehta TH, Garcia-Munoz A, Shepardson NE, Smith I, et al. (2008). Amyloid-beta protein dimers isolated directly from Alzheimer's brains impair synaptic plasticity and memory. Nature medicine, 14: 837-842

[148] Fitzjohn SM, Irving AJ, Palmer MJ, Harvey J, Lodge D, Collingridge GL (1996). Activation of group I mGluRs potentiates NMDA responses in rat hippocampal slices. Neuroscience letters, 203: 211-213

[149] Alagarsamy S, Marino MJ, Rouse ST, Gereau Iv RW, Heinemann SF, Conn PJ (1999). Activation of NMDA receptors reverses desensitization of mGluR5 in native and recombinant systems. Nature neuroscience, 2: 234240

[150] Bruno V, Copani A, Knopfel T, Kuhn R, Casabona G, Dell'Albani P, et al. (1995). Activation of metabotropic glutamate receptors coupled to inositol phospholipid hydrolysis amplifies NMDA-induced neuronal degeneration in cultured cortical cells. Neuropharmacology, 34: 1089-1098

[151] Bruno V, Ksiazek I, Battaglia G, Lukic S, Leonhardt T, Sauer D, et al. (2000). Selective blockade of metabotropic glutamate receptor subtype 5 is neuroprotective. Neuropharmacology, 39: 2223-2230

[152] Karanian DA, Baude AS, Brown QB, Parsons CG, Bahr BA (2006). 3-Nitropropionic acid toxicity in hippocampus: protection through N-methyl-D-aspartate receptor antagonism. Hippocampus, 16: 834-842

[153] Zieminska E, Lazarewicz JW (2006). Excitotoxic neuronal injury in chronic homocysteine neurotoxicity studied in vitro: the role of NMDA and group I metabotropic glutamate receptors. Acta neurobiologiae experimentalis, 66: 301-309

[154] Chen X, Lin R, Chang L, Xu S, Wei X, Zhang J, et al. (2013). Enhancement of long-term depression by soluble amyloid beta protein in rat hippocampus is mediated by metabotropic glutamate receptor and involves activation of p38MAPK, STEP and caspase-3. Neuroscience, 253: 435-443

[155] Hoover BR, Reed MN, Su J, Penrod RD, Kotilinek LA, Grant MK, et al. (2010). Tau mislocalization to dendritic spines mediates synaptic dysfunction independently of neurodegeneration. Neuron, 68: 10671081 .

[156] Kopeikina KJ, Hyman BT, Spires-Jones TL (2012). Soluble forms of tau are toxic in Alzheimer's disease. Transl Neurosci, 3: 223-233

[157] Crimins JL, Pooler A, Polydoro M, Luebke JI, SpiresJones TL (2013). The intersection of amyloid beta and tau in glutamatergic synaptic dysfunction and collapse in Alzheimer's disease. Ageing research reviews, 12: 757-763

[158] Roberson ED, Scearce-Levie K, Palop JJ, Yan F, Cheng IH, Wu T, et al. (2007). Reducing endogenous tau ameliorates amyloid beta-induced deficits in an Alzheimer's disease mouse model. Science (New York, N.Y.), 316: 750-754

[159] Rapoport M, Dawson HN, Binder LI, Vitek MP, Ferreira A (2002). Tau is essential to beta -amyloidinduced neurotoxicity. Proceedings of the National Academy of Sciences of the United States of America, 99: 6364-6369

[160] Roberson ED, Halabisky B, Yoo JW, Yao J, Chin J, Yan F, et al. (2011). Amyloid-beta/Fyn-induced synaptic, network, and cognitive impairments depend on tau levels in multiple mouse models of Alzheimer's disease. The Journal of neuroscience, 31: 700-711

[161] Nakazawa T, Komai S, Tezuka T, Hisatsune C, Umemori H, Semba K, et al. (2001). Characterization of Fyn-mediated tyrosine phosphorylation sites on GluR epsilon 2 (NR2B) subunit of the N-methyl-Daspartate receptor. The Journal of biological chemistry, 276: 693-699

[162] Chin J, Palop JJ, Yu GQ, Kojima N, Masliah E, Mucke L (2004). Fyn kinase modulates synaptotoxicity, but not aberrant sprouting, in human amyloid precursor protein transgenic mice. The Journal of neuroscience, 24: 4692-4697

[163] Chin J, Palop JJ, Puolivali J, Massaro C, Bien-Ly N, Gerstein H, et al. (2005). Fyn kinase induces synaptic and cognitive impairments in a transgenic mouse model of Alzheimer's disease. The Journal of neuroscience, 25: $9694-9703$

[164] Mondragon-Rodriguez S, Trillaud-Doppia E, Dudilot A, Bourgeois C, Lauzon M, Leclerc N, et al. (2012). 
Interaction of endogenous tau protein with synaptic proteins is regulated by N-methyl-D-aspartate receptordependent tau phosphorylation. The Journal of biological chemistry, 287: 32040-32053

[165] Beattie EC, Carroll RC, Yu X, Morishita W, Yasuda H, von Zastrow M, et al. (2000). Regulation of AMPA receptor endocytosis by a signaling mechanism shared with LTD. Nature neuroscience, 3: 1291-1300

[166] Hsieh H, Boehm J, Sato C, Iwatsubo T, Tomita T, Sisodia S, et al. (2006). AMPAR removal underlies Abeta-induced synaptic depression and dendritic spine loss. Neuron, 52: 831-843

[167] Reifert J, Hartung-Cranston D, Feinstein SC (2011). Amyloid beta-mediated cell death of cultured hippocampal neurons reveals extensive Tau fragmentation without increased full-length tau phosphorylation. The Journal of biological chemistry, 286: 20797-20811

[168] Takashima A, Noguchi K, Sato K, Hoshino T, Imahori $\mathrm{K}$ (1993). Tau protein kinase I is essential for amyloid beta-protein-induced neurotoxicity. Proceedings of the National Academy of Sciences of the United States of America, 90: 7789-7793

[169] Zheng WH, Bastianetto S, Mennicken F, Ma W, Kar S (2002). Amyloid beta peptide induces tau phosphorylation and loss of cholinergic neurons in rat primary septal cultures. Neuroscience, 115: 201-211

[170] Buckner RL, Sepulcre J, Talukdar T, Krienen FM, Liu H, Hedden T, et al. (2009). Cortical hubs revealed by intrinsic functional connectivity: mapping, assessment of stability, and relation to Alzheimer's disease. The Journal of neuroscience : the official journal of the Society for Neuroscience, 29: 1860-1873

[171] Cirrito JR, Yamada KA, Finn MB, Sloviter RS, Bales KR, May PC, et al. (2005). Synaptic activity regulates interstitial fluid amyloid-beta levels in vivo. Neuron, 48: 913-922

[172] Yamada K, Holth JK, Liao F, Stewart FR, Mahan TE, Jiang $\mathrm{H}$, et al. (2014). Neuronal activity regulates extracellular tau in vivo. The Journal of experimental medicine, 211: 387-393

[173] Wheeler DD, Ondo JG (1986). Time course of the aging of the high affinity L-glutamate transporter in rat cortical synaptosomes. Exp Gerontol., 21: 159-168.

[174] Najlerahim A, Francis PT, Bowen DM (1990). Agerelated alteration in excitatory amino acid neurotransmission in rat brain. Neurobiol Aging, 11: 155-158.

[175] Nickell J, Salvatore MF, Pomerleau F, Apparsundaram S, Gerhardt GA (2007). Reduced plasma membrane surface expression of GLAST mediates decreased glutamate regulation in the aged striatum. Neurobiol Aging., 28: 1737-1748. Epub 2006 Sep 1737.

[176] Meur KL, Galante M, Angulo MC, Audinat E (2007). Tonic activation of NMDA receptors by ambient glutamate of non-synaptic origin in the rat hippocampus. The Journal of Physiology, 580: 373-383

[177] Potier B, Billard J-M, Rivière S, Sinet P-M, Denis I, Champeil-Potokar G, et al. (2010). Reduction in glutamate uptake is associated with extrasynaptic NMDA and metabotropic glutamate receptor activation at the hippocampal CA1 synapse of aged rats. Aging Cell, 9: 722-735

[178] Nakanishi S, Masu M (1994). Molecular diversity and functions of glutamate receptors. Annual review of biophysics and biomolecular structure, 23: 319-348

[179] Karim F, Wang CC, Gereau RWt (2001). Metabotropic glutamate receptor subtypes 1 and 5 are activators of extracellular signal-regulated kinase signaling required for inflammatory pain in mice. The Journal of neuroscience, 21: 3771-3779

[180] Ayala JE, Chen Y, Banko JL, Sheffler DJ, Williams R, Telk AN, et al. (2009). mGluR5 positive allosteric modulators facilitate both hippocampal LTP and LTD and enhance spatial learning. Neuropsychopharmacology, 34: 2057-2071

[181] Neyman S, Manahan-Vaughan D (2008). Metabotropic glutamate receptor 1 (mGluR1) and 5 (mGluR5) regulate late phases of LTP and LTD in the hippocampal CA1 region in vitro. The European journal of neuroscience, 27: 1345-1352

[182] Biber K, Laurie DJ, Berthele A, Sommer B, Tolle TR, Gebicke-Harter PJ, et al. (1999). Expression and signaling of group I metabotropic glutamate receptors in astrocytes and microglia. Journal of neurochemistry, 72: $1671-1680$

[183] Kirischuk S, Kirchhoff F, Matyash V, Kettenmann H, Verkhratsky A (1999). Glutamate-triggered calcium signalling in mouse bergmann glial cells in situ: role of inositol-1,4,5-trisphosphate-mediated intracellular calcium release. Neuroscience, 92: 1051-1059

[184] Verkhratsky A, Kirchhoff F (2007). Glutamatemediated neuronal-glial transmission. Journal of anatomy, 210: 651-660

[185] Bond A, Ragumoorthy N, Monn JA, Hicks CA, Ward MA, Lodge D, et al. (1999). LY379268, a potent and selective Group II metabotropic glutamate receptor agonist, is neuroprotective in gerbil global, but not focal, cerebral ischaemia. Neuroscience letters, 273: 191-194

[186] Poschel B, Manahan-Vaughan D (2005). Group II mGluR-induced long term depression in the dentate gyrus in vivo is NMDA receptor-independent and does not require protein synthesis. Neuropharmacology, 49 Suppl 1: 1-12

[187] Yao HH, Ding JH, Zhou F, Wang F, Hu LF, Sun T, et al. (2005). Enhancement of glutamate uptake mediates the neuroprotection exerted by activating group II or III metabotropic glutamate receptors on astrocytes. Journal of neurochemistry, 92: 948-961

[188] Shigemoto R, Kinoshita A, Wada E, Nomura S, Ohishi H, Takada M, et al. (1997). Differential presynaptic localization of metabotropic glutamate receptor subtypes in the rat hippocampus. The Journal of neuroscience, 17: 7503-7522

[189] Pinheiro PS, Mulle C (2008). Presynaptic glutamate receptors: physiological functions and mechanisms of action. Nature reviews. Neuroscience, 9: 423-436 
[190] Geurts JJ, Wolswijk G, Bo L, Redeker S, Ramkema M, Troost D, et al. (2005). Expression patterns of Group III metabotropic glutamate receptors mGluR4 and mGluR8 in multiple sclerosis lesions. Journal of neuroimmunology, 158: 182-190

[191] Saugstad JA, Kinzie JM, Shinohara MM, Segerson TP, Westbrook GL (1997). Cloning and expression of rat metabotropic glutamate receptor 8 reveals a distinct pharmacological profile. Molecular pharmacology, 51: 119-125 